\title{
Thiophene-based donor-acceptor co-oligomers by copper-catalyzed 1,3-dipolar cycloaddition
}

\author{
Stefanie Potratz, Amaresh Mishra and Peter Bäuerle $§$
} Open Access

\begin{abstract}
Herein we present a three-component one-pot procedure to synthesize co-oligomers of a donor-acceptor-donor type, in which thiophene moieties work as donor and 1,2,3-triazoles as acceptor units. In this respect, terminally ethynylated (oligo)thiophenes were coupled to halogenated (oligo)thiophenes in the presence of sodium azide and a copper catalyst. Optoelectronic properties of various thiophene-1,2,3-triazole co-oligomers were investigated by UV-vis spectroscopy and cyclic voltammetry. Several co-oligomers were electropolymerized to the corresponding conjugated polymers.
\end{abstract}

\section{Introduction}

Oligo- and polythiophenes are among the most extensively investigated organic semiconducting materials used in organic electronics [1-3]. In this respect, various oligomers have been developed by using metal-catalyzed Suzuki-, Stille-, Sonogashira-, and Kumada-type cross-coupling reactions [4-9]. On the other hand, the so-called "click chemistry", originally reported by Sharpless and co-workers in 2001, has played a significant role as a versatile strategy for the rapid and efficient assembly of a pair of functional molecular building blocks under mild reaction conditions [10]. It guarantees reliable synthesis of the desired products in high yield and purity. Click reactions generally involve a $\mathrm{Cu}(\mathrm{I})$-catalyzed version of the Huisgen 1,3-dipolar cycloaddition of terminal acetylenes and azides (CuAAC), to regioselectively yield 1,4-disubstituted $1 H$-1,2,3-triazoles [11,12]. In the meanwhile, this type of click reaction has become very popular and reached high significance in materials synthesis, because high yields and easy to purify products are typically obtained $[13,14]$. The click chemistry approach was successfully employed to synthesize various oligomers [15-17], catenanes and rotaxanes [18], dendrimers $[11,19,20]$, and polymers [21-23], and was used for DNA labelling [24,25], sensors [26,27], and metal chelates [28-30], due to the mild reaction conditions and compatibility with a variety of functional groups. However, the electronic conjugation through the resulting 1,2,3-triazole rings is weak due to poor electronic communication between the chromophores [21- 
$23,31]$. It has also been shown that a 1,2,3-triazole can act as a strong $\sigma$-electron donor [26] or as a weak $\pi$-electron acceptor [15].

In this study, we aimed at the combination of electron-rich (oligo)thiophenes as donors and electron-deficient 1,2,3-triazole rings as acceptors to conveniently build up novel donor-acceptor co-oligomeric and copolymeric materials by click chemistry. Thereby, the inherent instability of 2-azidothiophene was a problem.

\section{Results and discussion}

In 2005, Liang et al. [32] described a mild, copper-catalyzed method to synthesize aromatic azides from halogenated arenes and sodium azide. We have now transferred this method to the synthesis of 3-azidothiophene (2) from 3-iodothiophene (1) in excellent yield, which in the following was used for further click reactions to form novel thienyl-1,2,3-triazole co-oligomers (Scheme 1). In contrast, 2-azidothiophene could not be obtained by this protocol, because it is inherently instable. This finding corresponds to the observations of Zanirato et al. that, depending on the nature of the substituents, 5-substituted 2-azidothiophenes are more or less instable at elevated temperatures [33].

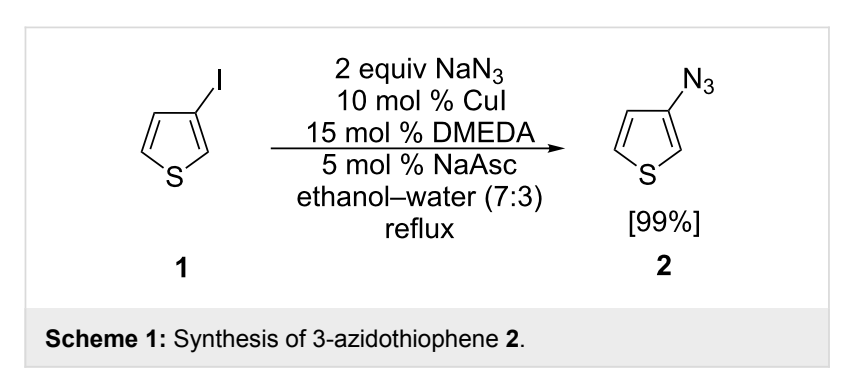

In order to overcome this inherent problem, we used a one-pot, two-step sequence, whereby an organic azide was generated in situ from a corresponding halide and immediately consumed in a reaction with copper acetylide [34-36]. Thus, as a model, we optimized the reaction of 2-halogenothiophene 3 and 2-ethynylthiophene (4) in the presence of sodium azide and a copper(I) catalyst to yield co-oligomer 1,4-di(thien-2-yl)-1,2,3triazole (5) (Scheme 2).
We first used the Fokin protocol [34], which worked well for phenyl halides and in which 1.2 equiv of sodium azide, $10 \mathrm{~mol} \%$ of cupric sulfate, $10 \mathrm{~mol} \%$ sodium ascorbate, which reduces $\mathrm{Cu}(\mathrm{II})$ to $\mathrm{Cu}(\mathrm{I}), 10 \mathrm{~mol} \%$ sodium carbonate and $20 \mathrm{~mol} \% \mathrm{~L}$-proline as ligand were reacted in the solvent system DMSO-water at $60{ }^{\circ} \mathrm{C}$. The co-oligomeric product 5 was obtained in only $10 \%$ yield (Table 1 , entry 1 ). When the stabilizing ligand was changed to $N, N$ '-dimethylethylenediamine (DMEDA) according to Liang et al. [32] the yield of 1,4di(thien-2-yl)-1,2,3-triazole (5) was increased to $17 \%$ (entry 2). Careful choice of solvent mixture and temperature finally raised the yield of 5 to $59 \%$ when ethanol-water $(7: 3)$ at $50{ }^{\circ} \mathrm{C}$ was used (entry 4). Lower temperatures gave an incomplete conversion of 2-iodothiophene (3), whereas at $95{ }^{\circ} \mathrm{C}$ the 2 -azidothiophene eventually decomposed. Therefore, we found that a temperature of $50{ }^{\circ} \mathrm{C}$ was a good compromise between the reactivity of the halogenated thiophene in the nucleophilic substitution to 2-azidothiophene, and the stability of the in situ formed azido derivative.

\begin{tabular}{|c|c|c|c|c|}
\hline entry & ligand & solvent & $T\left[{ }^{\circ} \mathrm{C}\right]$ & yield [\%] \\
\hline 1 & L-proline & DMSO-water (9:1) & 60 & 10 \\
\hline 2 & DMEDA & DMSO-water (9:1) & 50 & 17 \\
\hline 3 & DMEDA & tert-butanol-water $(2: 1)$ & 50 & 28 \\
\hline 4 & DMEDA & ethanol-water $(7: 3)$ & 50 & 59 \\
\hline 5 & DMEDA & ethanol-water $(7: 3)$ & 20 & 39 \\
\hline 6 & DMEDA & ethanol-water $(7: 3)$ & 95 & 16 \\
\hline
\end{tabular}

Under the optimized reaction conditions for the preparation of di(thien-2-yl)-1,2,3-triazole 5 (2 equiv $\mathrm{NaN}_{3}, 10 \mathrm{~mol} \%$ copper(I) iodide, $10 \mathrm{~mol} \%$ sodium ascorbate, $20 \mathrm{~mol} \%$ DMEDA, ethanol-water $(7: 3), 50{ }^{\circ} \mathrm{C}$ for $15 \mathrm{~h}$, entry 4$)$ a series of conjugated benzene- and thiophene-1,2,3-triazole co-oligomers was synthesized in good to excellent yields (Table 2). By systematic variation of the halogenated and the ethynylated reagent, general trends could be deduced: (a) Iodides react better than bromides $(\mathbf{5}, \mathbf{6}, \mathbf{8},(\mathbf{9}), \mathbf{1 0})$; (b) Due to

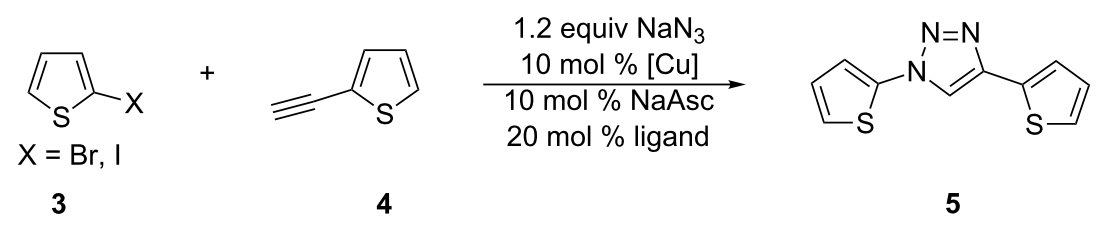

Scheme 2: One-pot, two-step procedure to give a dithienyl-1,2,3-triazole co-oligomer 5 . See Table 1 for detailed conditions. 
Table 2: Synthesis of 1,4-disubstituted 1,2,3-triazoles from corresponding halides (1 equiv), terminal acetylenes (1 equiv) and sodium azide (2 equiv) in the presence of copper(I) iodide (10 mol \%), sodium ascorbate $(10 \mathrm{~mol} \%)$ and $N, N$ '-dimethylethylenediamine (DMEDA, $20 \mathrm{~mol} \%)$ in ethanol-water $(7: 3)$ at $50{ }^{\circ} \mathrm{C}$ for $15 \mathrm{~h}$. The yields are for pure compounds and are averages of two runs.

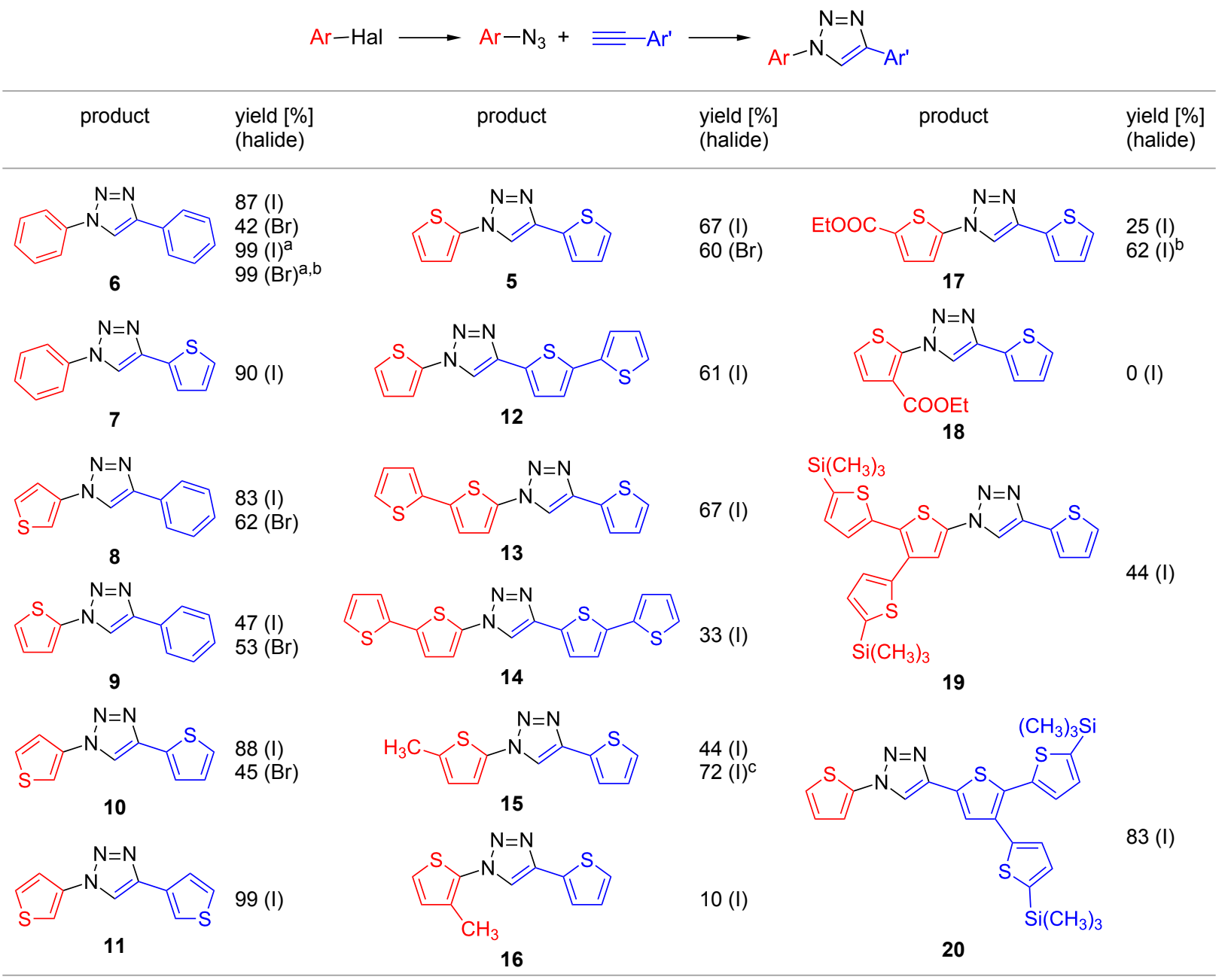

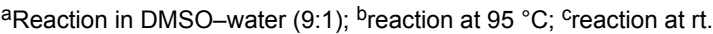

the higher stability of 3-versus 2-azidothiophenes, 3-halogenated thiophenes give higher yields than 2-halogenated thiophenes, 2-substituted benzenes higher yields than thiophenes, and thiophenes higher yields than bithiophenes.

As expected, 3-halogenothiophenes gave higher yields than 2-halogenothiophenes (e.g., 8 and 9), because of the higher nucleophilicity in azide formation. Additionally, 3-azidothiophenes are much more stable than 2-azidothiophenes [37]. In the series of halides, benzenes gave higher yields than monoand bithiophenes; the lowest conversion was observed for the branched terthiophene to form co-oligomer 19, which is a result of the instability of the intermediate azide. The electrondonating methyl group in the 5-position of the thiophene ring destabilizes the corresponding azide, therefore low conversion to 15 was observed. The yield was increased with decreasing temperature. Electron-withdrawing ester groups showed an opposite tendency. Due to the lower nucleophilicity of ethyl 5-iodothiophene-2-carboxylate, the conversion to $\mathbf{1 7}$ rose with increasing temperature.

Substituents in the 3-position of 2-iodothiophenes gave low or no conversion to $\mathbf{1 6}$ and $\mathbf{1 8}$, respectively, because of steric hindrance in the copper-catalyzed azide formation. Twofold reactions were also investigated under the optimized reaction conditions. 1,4-Dihalogenobenzene was reacted with 2-ethynylthiophene in excellent yields (Scheme 3). 1,4Diiodobenzene gave the desired product 21 in $99 \%$ yield at $50{ }^{\circ} \mathrm{C}$, whereas 1,4-dibromobenzene was disubstituted at $95{ }^{\circ} \mathrm{C}$ in $98 \%$ yield. 


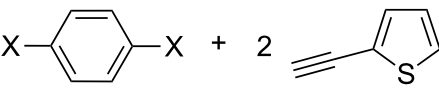

$\mathrm{X}=\mathrm{Br}, \mathrm{I}$

2 equiv $\mathrm{NaN}_{3}$ $10 \mathrm{~mol}_{0} \mathrm{CuSO}_{4}$

$\Delta$

$10 \mathrm{~mol} \% \mathrm{NaAsc}$

$20 \mathrm{~mol} \%$ DMEDA

DMSO- $\mathrm{H}_{2} \mathrm{O}(9: 1)$

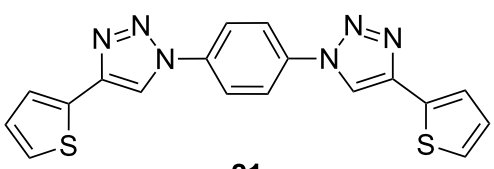

21

Scheme 3: Synthesis of 1,4-bis[4-(thiophen-2-yl)-1H-1,2,3-triazol-1-yl] benzene 21 .
UV-vis absorption spectra of co-oligomers 5, 6 and 10-14 revealed absorption bands of the individual subunits (Figure 1, Table 3). Thus, for triazole 5 an absorption band at $279 \mathrm{~nm}$ was observed, which is rather comparable to the absorption of 2-vinylthiophene (276 nm in ethanol) [38]. The second absorption band at $256 \mathrm{~nm}$ was assigned to the thiophene ring attached to the 1-position of the triazole. The evidence for intramolecular charge-transfer (ICT) [39] in 5 was investigated in several solvents with different dielectric constants: $n$-hexane $(\varepsilon=1.9)$, THF $(\varepsilon=7.6)$, methanol $(\varepsilon=32.6)$, and acetonitrile $(\varepsilon=37.5)$. Typically, no ICT was found in the described thiophene-triazole co-oligomers, but aggregate formation was observed in THF and $n$-hexane due to low solubility. For derivative 14 an absorption maximum at $353 \mathrm{~nm}$ was observed, which is red-shifted in comparison to that of $\mathbf{1 2}\left(\lambda_{\max }=\right.$ $337 \mathrm{~nm})$ and $13\left(\lambda_{\max }=339 \mathrm{~nm}\right)$. This band is not ascribed to individual bithienyl subunits, but to a weak conjugation through the triazole ring, caused by the donor-acceptor-donor system. Maarseveen et al. recently published synthesis and optical prop-
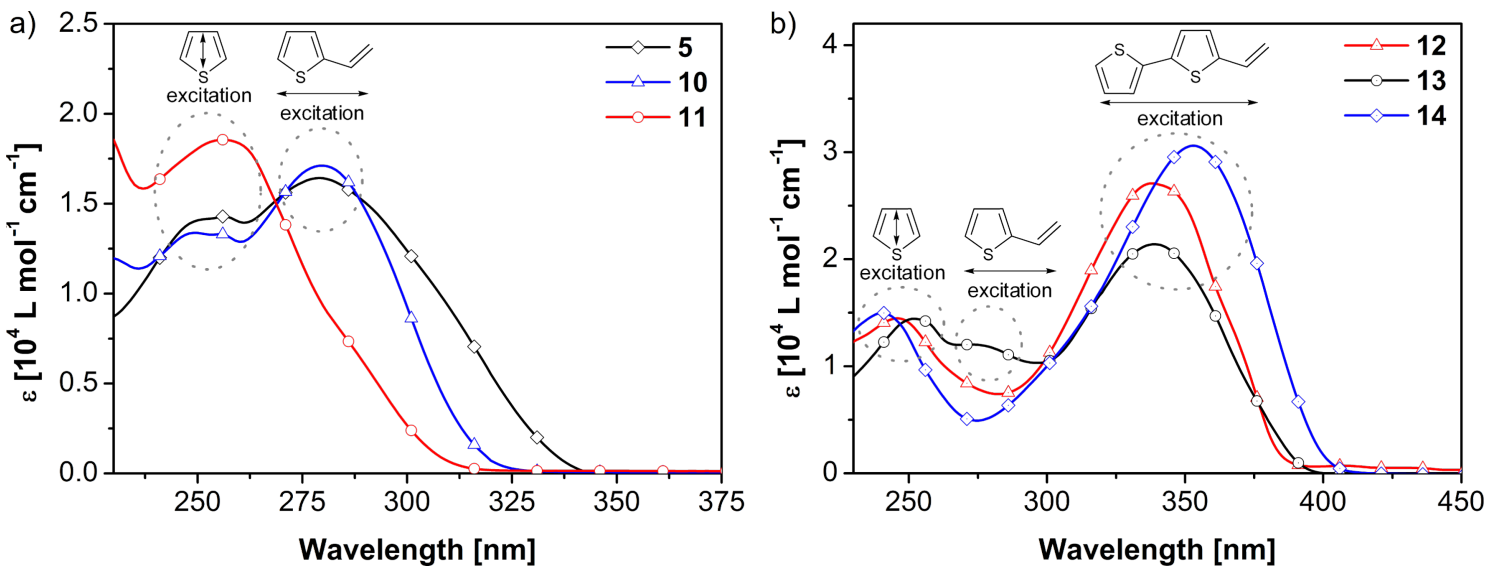

Figure 1: UV-vis spectra of 5, 10 and $11(a)$ and 12-14 (b) in dichloromethane $\left([c]=5 \times 10^{-5} \mathrm{M}\right)$ at room temperature.

Table 3: Spectroscopic and electrochemical characterization of 5, 6 and 10-14.

\begin{tabular}{|c|c|c|c|c|c|}
\hline & $\lambda^{\mathrm{abs}}[\mathrm{nm}]^{\mathrm{a}}$ & $\lambda^{e m} \max [n m]$ & $\Phi[\%]^{\mathrm{b}}$ & Stokes shift $\left[\mathrm{cm}^{-1}\right]^{\mathrm{c}}$ & $E_{o x}^{0}[\mathrm{~V}]^{\mathrm{d}}$ \\
\hline 5 & $250,256,279$ & & & & 1.15 \\
\hline 6 & 250 & & & & 1.45 \\
\hline 10 & $248,256,279$ & & & & 1.13 \\
\hline 11 & 230,256 & & & & 1.23 \\
\hline 12 & 244,337 & 403 & 6 & 4860 & 0.71 \\
\hline 13 & $256,273,339$ & 414 & 10 & 5344 & 0.89 \\
\hline 14 & 240,353 & 424 & 14 & 4744 & 0.69 \\
\hline
\end{tabular}

aMaxima in italics $\left(5 \times 10^{-5} \mathrm{M}\right.$ in dichloromethane); b ${ }^{\mathrm{a}}$ quantum yields determined with respect to DPA [41]; ' $S$ tokes shift is given for the $0 \rightarrow 00^{*}$ transition $\left(\Delta \mathrm{v}=\mathrm{v}^{\mathrm{abs}}{ }_{\max }-\mathrm{v}^{\mathrm{em}} \mathrm{max}_{\max }\right)$, dirreversible redox process, $E_{\text {ox }}^{0}$ determined at $I_{0}=0.855 \times I_{\mathrm{p}}[42]$. 
erties of 1,2,3-triazole containing co-polymers, suggesting that triazole rings interrupt conjugation and therefore no interaction of the various moieties of the polymer was observable [21].

Fluorescence spectra $\left(10^{-6} \mathrm{M}\right.$ for 12 and $\mathbf{1 3}, 5 \times 10^{-7} \mathrm{M}$ for 14 in dichloromethane, Table 3) of investigated compounds 12-14 showed structured bands due to vibronic splitting. The red-shift of the emission maximum of $\mathbf{1 4}$ in comparison to $\mathbf{1 2}$ and $\mathbf{1 3}$ confirmed the facts assumed from UV-vis spectra that there should be weak electronic communication in the oligomers going through the 1,2,3-triazole ring. Fluorescence quantum yields of 6 to $14 \%$ were determined which are rather high for bithiophenes (1.8\%) [40] and increased with increasing molecular size and conjugation. Obviously, the 1,2,3-triazole ring stabilizes the excited state by decreasing the probability of nonradiative deactivation.

Comparable to the optical properties, cyclic voltammetry of $\mathbf{5}$, 6, and 10-14 revealed redox transitions of the individual thiophene moieties (Table 3$)$. Thus, cyclic voltammograms (CV) of 5 and $\mathbf{1 0}\left(5 \times 10^{-3} \mathrm{M}\right.$ in dichloromethane/tetrabutylammonium hexafluorophosphate $\left(\mathrm{TBAPF}_{6}, 0.1 \mathrm{M}, 100 \mathrm{mV} \mathrm{s}^{-1}\right.$ ) showed characteristic oxidation waves of the 2-vinylthiophene subunit at $1.15 \mathrm{~V}$ and $1.13 \mathrm{~V}$ vs $\mathrm{Fc} / \mathrm{Fc}^{+}$, respectively. For co-oligomer 11, the oxidation potential was significantly higher $(1.23 \mathrm{~V})$ and indicates formation of a radical cation localized on the thiophene subunits. In the negative regime, no reduction wave for the 1,2,3-triazole unit could be observed.

From the optoelectronic data we deduced a HOMO-LUMO energy level diagram including band gaps for the novel donor-acceptor materials 5, 6 and 10-14 (Figure 2). HOMO values were taken from the onset of oxidation and the internal reference $\mathrm{Fc} / \mathrm{Fc}^{+}$was set to $-5.1 \mathrm{eV}$ versus vacuum. The LUMO values were calculated by taking the optical band gaps into account, which were taken from the absorption onset at the lowest energy band. As a trend it can be seen that 3-thienyl derivative 11 has the largest band gap (4.04 eV), because the thiophenes are linked to the triazole by unfavorable $\beta$-connections. The gap successively decreases the more extended the conjugated $\pi$-system is and approaches $3.11 \mathrm{eV}$ for $\alpha$-connected bithienyl derivative $\mathbf{1 4}$.

Oxidative oligo- and polymerization of derivatives 12-14 was carried out by potentiodynamic cycling in the appropriate potential range. The films, which were deposited on the platinum working electrode within 30 cycles, were investigated in monomer-free dichloromethane solution. The CVs indicated that only dimers of $\mathbf{1 2}$ and $\mathbf{1 3}$ were formed, which showed quasi-reversible oxidation waves at $0.28 \mathrm{~V}$ and $0.68 \mathrm{~V}$ versus $\mathrm{Fc} / \mathrm{Fc}^{+}$, respectively, corresponding to a divinyl-quaterthio-

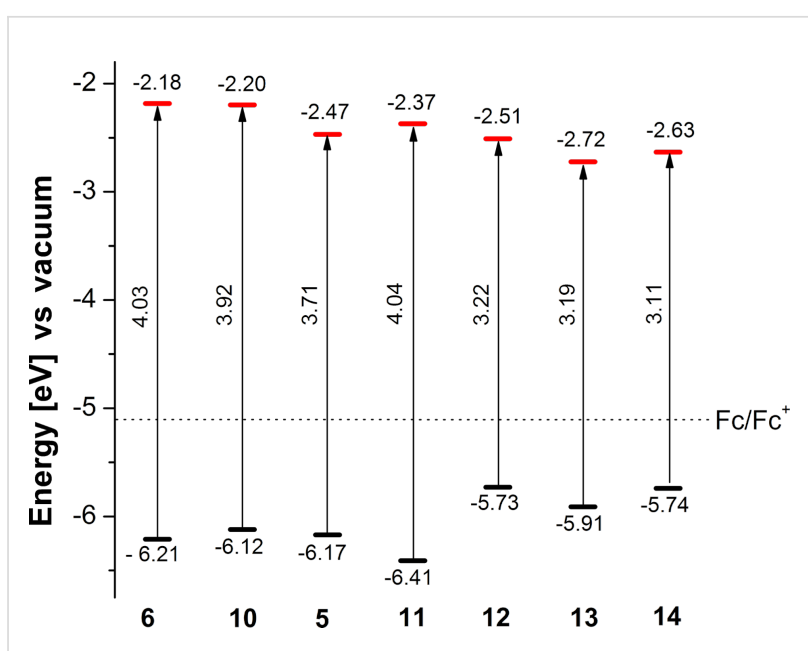

Figure 2: HOMO-LUMO energy level diagram for thiophene-triazole co-oligomers 5, 6, 10-14.

phene unit in $\mathbf{1 2}$ and a quaterthiophene in 13. Electrochemical polymerization of $\mathbf{1 4}$ performed on a platinum working electrode in the range of -0.9 to $0.8 \mathrm{~V}$ versus $\mathrm{Fc} / \mathrm{Fc}^{+}$within 30 cycles is displayed in Figure 3 (monomer 14: red, polymerization: gray, polymer film: blue). Because of similar oxidation potentials for both bithienyl subunits in $\mathbf{1 4}$ the formation of higher co-oligomers and co-polymers can be expected and the oxidation onset was located at $-0.17 \mathrm{~V}$. Therefore, comparable electronic structures in the oligo- and polymers are responsible for this redox behavior.

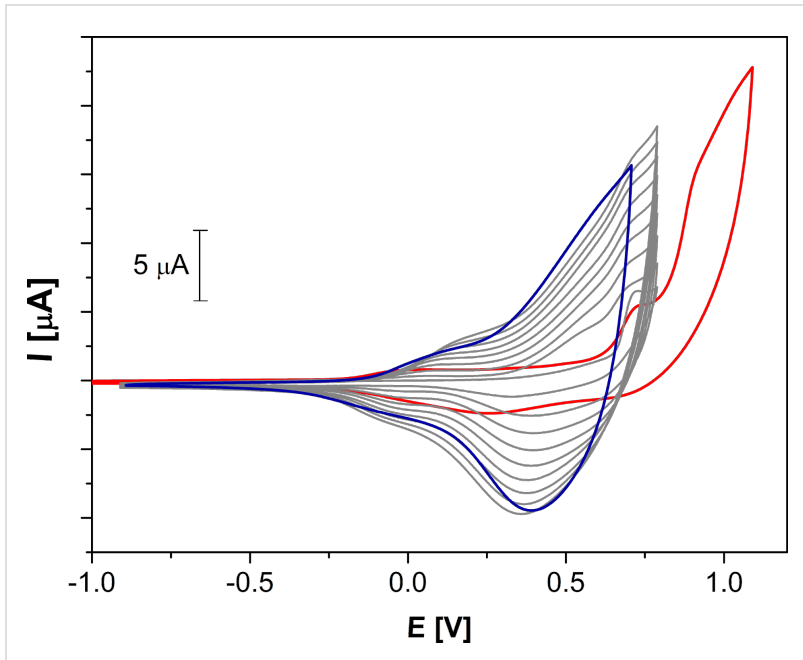

Figure 3: Cyclic voltammogram of bithienyl-triazole 14 in dichloromethane/TBAPF $6(0.1 \mathrm{M})$ versus $\mathrm{Fc}_{6} / \mathrm{Fc}^{+}$at $100 \mathrm{mV} \mathrm{s}^{-1}$ (red: monomer 14, gray: during polymerization, blue: polymer film).

\section{Conclusion}

In summary, a series of novel thiophene-1,2,3-triazole co-oligomers was synthesized in good to excellent yields by a 
three-component two-step procedure using copper-catalyzed $[3+2]$-Huisgen cycloaddition reactions. Spectroscopic and redox properties of selected donor-acceptor-donor derivatives were investigated, in which thiophene units act as donors and triazoles as acceptors. As a general result we find that weak electronic conjugation through the 1,2,3-triazole ring is operative.

\section{Experimental \\ General information}

All reactions were carried out under an inert atmosphere of argon. All chemicals were used as received without further purification unless otherwise specified. Thin-layer chromatography (TLC) was carried out on silica gel $60 \mathrm{~F}_{254}$ aluminium plates (Merck). Developed plates were dried and examined under a UV lamp. Preparative-column chromatography was carried out on glass columns of different diameters packed with silica gel, Merck $60(40-63 \mu \mathrm{m})$. Gas chromatography (GC) was carried out using a Varian CP-3800 gas chromatograph. Helium 5.0 was used as the carrier gas; signals were examined by a flame-ionization detector (FID). Gas-chromatography-mass-spectrometry (GC-MS) measurements were executed with a Varian 3800 . Helium 5.0 was used as the carrier gas; mass spectra were recorded on a Varian Saturn 2000. Ions were generated by electron impact (EI). Melting points were determined in a Büchi B-545 apparatus and are uncorrected. NMR spectra were recorded in $\mathrm{CDCl}_{3}$, DMSO- $d_{6}$ or THF- $d_{8}$ on a Bruker AMX 400 at $400 \mathrm{MHz}\left({ }^{1} \mathrm{H}\right.$ nuclei) and $100 \mathrm{MHz}\left({ }^{13} \mathrm{C}\right.$ nuclei), respectively. Chemical shifts are denoted in $\delta$ units (ppm) and are referenced to the solvent signal (7.26 ppm for $\mathrm{CDCl}_{3}, 2.50 \mathrm{ppm}$ for DMSO- $d_{6}$ and 1.73 for THF- $\left.d_{8}\right)$. The splitting patterns are designated as follows: $s$ (singlet), d (doublet), $\mathrm{t}$ (triplet), $\mathrm{m}$ (multiplet). Mass spectra were measured at Finnigan MAT, SSQ 7000 by CI and Bruker Daltonics REFLEX III by MALDI-TOF. Elemental analysis for $\mathrm{C}, \mathrm{H}$ and $\mathrm{N}$ were determined at Elementar Vario EL and for $\mathrm{S}$ at Carlo Erba 1104. High-resolution mass spectra were measured on a micrOTOF-Q 43 with electron spray ionization (ESI) and atmospheric-pressure chemical ionization (APCI). UV-vis spectra were taken on a Perkin-Elmer Lambda 19 in $1 \mathrm{~cm}$ cuvettes. Fluorescence spectra were measured with a PerkinElmer LS 55 in $1 \mathrm{~cm}$ cuvettes. Fluorescence quantum yields were determined with respect to 9,10-diphenylanthracene (DPA, $\Phi=0.9$ in dichloromethane) [43]. Cyclic voltammetry experiments were performed with a computer-controlled EG\&G PAR 273 potentiostat in a three-electrode single-compartment cell $(2 \mathrm{~mL})$. The platinum working electrode consisted of a platinum wire sealed in a soft glass tube with a surface area of $A$ $=0.785 \mathrm{~mm}^{2}$, which was polished down to $0.5 \mu \mathrm{m}$ with Buehler polishing paste prior to use. The counter electrode consisted of a platinum wire and the reference electrode was an $\mathrm{Ag} / \mathrm{AgCl}$ secondary electrode. All potentials were internally referenced to the ferrocene/ferricenium couple. For the measurements, the electroactive species were used in freshly distilled and degassed dichloromethane and $0.1 \mathrm{M}$ tetrabutylammonium hexafluorophosphate $\left(\mathrm{TBAPF}_{6}\right.$, Fluka), which was twice recrystallized from ethanol and dried under vacuum prior to use. 5'-Iodo-5,5"bis(trimethylsilyl)-[2,2':3',2"terthiophene] and 2-[5,5"bis(trimethylsilyl)-[2,2':3',2"-terthien]-5'-yl]ethynyl-1-trimethylsilane were synthesized according to the literature [44].

3-Azidothiophene (2): In a mixture of ethanol $(2.8 \mathrm{~mL})$ and water (1.2 mL) 3-iodothiophene (1, $0.22 \mathrm{~mL}, 2 \mathrm{mmol})$, copper(I) iodide (38 mg, $0.2 \mathrm{mmol})$, sodium ascorbate (20 mg, $0.1 \mathrm{mmol})$, sodium azide ( $0.26 \mathrm{~g}, 4 \mathrm{mmol})$, and DMEDA (0.03 $\mathrm{mL}, 0.3 \mathrm{mmol})$ were dissolved and heated under refluxed under argon until TLC (silica/DCM) showed complete consumption of the starting material. After five hours the cooled brown mixture was diluted with water $(10 \mathrm{~mL})$ and ethyl acetate $(10 \mathrm{~mL})$. The aqueous phase was extracted with ethyl acetate (2 times, $10 \mathrm{~mL}$ ). After the organic phases were washed with brine $(15 \mathrm{~mL})$ they were dried over sodium sulfate and evaporated to dryness in vacuum at room temperature. Because of the instability of the product on silica it was used without further purification. The NMR data was consistent with literature data [45]. ${ }^{1} \mathrm{H}$ NMR $\left(400 \mathrm{MHz}, \mathrm{CDCl}_{3}\right) \delta 6.79(\mathrm{dd}, J=1.5$ and $3.2 \mathrm{~Hz}$, $1 \mathrm{H}), 6.82(\mathrm{dd}, J=1.4$ and $5.2 \mathrm{~Hz}, 1 \mathrm{H}), 7.30(\mathrm{dd}, J=3.2$ and 5.1 $\mathrm{Hz}, 1 \mathrm{H})$.

\section{General procedure for the synthesis of 1,4- disubstituted $1 H$-1,2,3-triazoles}

Halide ( 1 equiv) and terminal acetylene (1 equiv) were dissolved in an ethanol/water mixture $(4 \mathrm{~mL}, 7: 3)$. After the addition of sodium azide ( 2 equiv), sodium ascorbate (10 mol \%), N,N'-dimethylethylenediamine (DMEDA, $20 \mathrm{~mol} \%$ ) and copper(I) iodide (10 mol \%), the mixture was stirred in a closed Schlenk tube at $50{ }^{\circ} \mathrm{C}$ for about 15 hours. The cooled mixture was poured into $50 \mathrm{~mL}$ ice-water. If the product precipitated (method A) it was filtered off and washed with $\mathrm{NH}_{4} \mathrm{OH}(25 \%)$ and water. The dried product was purified by column chromatography. The non-precipitating products (method B) were treated with $10 \mathrm{~mL} \mathrm{NH}_{4} \mathrm{OH}(25 \%)$. The aqueous solution was washed three times with $50 \mathrm{~mL}$ ethyl acetate. After the organic phase was dried over sodium sulfate, the crude product was concentrated at the rotary evaporator and purified on silica.

1,4-Di(thien-2-yl)-1H-1,2,3-triazole (5): 2-Iodothiophene $(0.11 \mathrm{~mL}, 1 \mathrm{mmol})$ or 2-bromothiophene $(0.10 \mathrm{~mL}, 1 \mathrm{mmol})$, 2-ethynylthiophene $(0.11 \mathrm{mg}, 1 \mathrm{mmol})$, sodium azide (130 mg, $2 \mathrm{mmol}$ ), copper(I) iodide (19 mg, $0.1 \mathrm{mmol})$, sodium ascorbate $(20 \mathrm{mg}, 0.1 \mathrm{mmol})$, DMEDA $(20 \mu \mathrm{L}, 0.2 \mathrm{mmol})$. Method 
A gave the white product in $0.161 \mathrm{~g}(0.69 \mathrm{mmol}, 69 \%)$ from 2-iodothiophene and $0.186 \mathrm{~g}(0.80 \mathrm{mmol}, 60 \%)$ from 2-bromothiophene. mp $125-126{ }^{\circ} \mathrm{C}$ (from toluene); ${ }^{1} \mathrm{H}$ NMR $\left(400 \mathrm{MHz}, \mathrm{CDCl}_{3}\right) \delta 7.06(\mathrm{dd}, J=3.8$ and $5.5 \mathrm{~Hz}, 1 \mathrm{H}), 7.11$ $(\mathrm{dd}, J=3.6$ and $5.1 \mathrm{~Hz}, 1 \mathrm{H}), 7.25(\mathrm{dd}, J=1.4$ and $5.5 \mathrm{~Hz}, 1 \mathrm{H})$, $7.29(\mathrm{dd}, J=1.4$ and $3.8 \mathrm{~Hz}, 1 \mathrm{H}), 7.35(\mathrm{dd}, J=1.1$ and $5.1 \mathrm{~Hz}$, $1 \mathrm{H}), 7.48(\mathrm{dd}, J=1,1$ and $3.6 \mathrm{~Hz}, 1 \mathrm{H}), 8.00(\mathrm{~s}, 1 \mathrm{H}) ;{ }^{13} \mathrm{C} \mathrm{NMR}$ $\left(100 \mathrm{MHz}, \mathrm{CDCl}_{3}\right) \delta 118.30,118.35,122.98,124.80,125.59$, 126.29, 126.32, 132.04; CIMS $m / z:(\mathrm{M}+\mathrm{H}) 234,\left(\mathrm{M}-\mathrm{N}_{2}\right) 206$ Anal. calcd for $\mathrm{C}_{10} \mathrm{H}_{7} \mathrm{~N}_{3} \mathrm{~S}_{2}$ : C, 51.48; H, 3.02; N, 18.01; S, 27.49; found: C, 51.54; H, 3.13; N, 17.92; S, 26.87.

1,4-Diphenyl-1H-1,2,3-triazole (6): Iodobenzene $(0.11 \mathrm{~mL}$, $1 \mathrm{mmol})$ or bromobenzene $(0.11 \mathrm{~mL}, 1 \mathrm{mmol})$, phenylacetylene $(0.11 \mathrm{~mL}, 1 \mathrm{mmol})$, sodium azide $(0.13 \mathrm{~g}, 2 \mathrm{mmol})$, copper(I) iodide (19 mg, $0.1 \mathrm{mmol})$, sodium ascorbate $(20 \mathrm{mg}, 0.1 \mathrm{mmol})$, DMEDA $(20 \mu \mathrm{L}, 0.2 \mathrm{mmol})$. Method A gave triazole 6 in $0.199 \mathrm{~g}(0.90 \mathrm{mmol}, 90 \%)$ from iodobenzene and in $0.923 \mathrm{~g}$ (0.42 mmol, $42 \%)$ from bromobenzene as a white solid. Changing the solvent to DMSO-water (9:1) gave 6 in $0.22 \mathrm{~g}$ (0.99 mol, 99\%) from iodothiophene at $60{ }^{\circ} \mathrm{C}$ and bromobenzene at $95{ }^{\circ} \mathrm{C}$, respectively. The analytical data correspond to literature data [21]. ${ }^{1} \mathrm{H}$ NMR $\left(400 \mathrm{MHz}, \mathrm{CDCl}_{3}\right) \delta 7.37(\mathrm{~m}$, 1H), $7.47(\mathrm{~m}, 3 \mathrm{H}), 7.56(\mathrm{~m}, 2 \mathrm{H}), 7.80(\mathrm{~m}, 2 \mathrm{H}), 7.92(\mathrm{~m}, 2 \mathrm{H})$, $8.15(\mathrm{~s}, 1 \mathrm{H}) ;{ }^{13} \mathrm{C} \mathrm{NMR}\left(100 \mathrm{MHz}, \mathrm{CDCl}_{3}\right) \delta 120.6,125.9$, $128.4,128.8,128.9,129.8$.

1-Phenyl-4-(thien-2-yl)-1H-1,2,3-triazole (7): Iodobenzene (0.11 mL, $1 \mathrm{mmol})$, 2-ethynylthiophene $(4,0.11 \mathrm{~g}, 1 \mathrm{mmol})$, sodium azide (130 mg, $2 \mathrm{mmol}$ ), copper(I) iodide (19 mg, $0.1 \mathrm{mmol})$, sodium ascorbate $(20 \mathrm{mg}, 0.1 \mathrm{mmol})$, DMEDA $(20 \mu \mathrm{L}, 0.2 \mathrm{mmol})$. Method A gave the colorless product in $213.6 \mathrm{mg}(940 \mu \mathrm{mol}, 94 \%) \mathrm{mp} 136-137{ }^{\circ} \mathrm{C}$ (from EE- $n$ hexane); ${ }^{1} \mathrm{H}$ NMR (400 MHz, $\left.\mathrm{CDCl}_{3}\right) \delta 7.12$ (dd, $J=3.6$ and $5.1 \mathrm{~Hz}, 1 \mathrm{H}), 7.35(\mathrm{dd}, J=1.1$ and $5.1 \mathrm{~Hz}, 1 \mathrm{H}), 7.47(\mathrm{t}, J=7.3$ $\mathrm{Hz}, 1 \mathrm{H}), 7.49(\mathrm{dd}, J=1.1$ and $3.3 \mathrm{~Hz}, 1 \mathrm{H}), 7.56(\mathrm{t}, J=7.7 \mathrm{~Hz}$, $2 \mathrm{H}), 7.78(\mathrm{~d}, J=7.4 \mathrm{~Hz}, 2 \mathrm{H}), 8.11(\mathrm{~s}, 1 \mathrm{H}) ;{ }^{13} \mathrm{C}$ NMR $(100$ $\left.\mathrm{MHz}, \mathrm{CDCl}_{3}\right) \delta 117.06,120.57,124.56,125.38,127.71$, $128.88,129.80,132.50,136.93,143.52$; Anal. calcd for $\mathrm{C}_{12} \mathrm{H}_{9} \mathrm{~N}_{3} \mathrm{~S}$ : C, 63.41; H, 3.99; N, 18.49; S, 14.11; found: C, 63.40; H, 4.07; N, 18.44; S, 14.43; CIMS $m / z$ : $(\mathrm{M}+\mathrm{H}) 228$, (M $\left.-\mathrm{N}_{2}\right) 199$.

4-Phenyl-1-(thien-3-yl)-1H-1,2,3-triazole (8): 3-Iodothiophene $(1,0.13 \mathrm{~mL}, 1 \mathrm{mmol})$, phenylacetylene $(0.11 \mathrm{~mL}$, $1 \mathrm{mmol}$ ), sodium azide (130 mg, $2 \mathrm{mmol}$ ), copper(I) iodide (19 $\mathrm{mg}, 0.1 \mathrm{mmol})$, sodium ascorbate $(20 \mathrm{mg}, 0.1 \mathrm{mmol})$, DMEDA (20 $\mu \mathrm{L}, 0.2 \mathrm{mmol})$. Method A gave the pure off-white product in $0.186 \mathrm{~g}(0.82 \mathrm{mmol}, 82 \%)$ from 3-iodothiophene and $0.145 \mathrm{~g}$ (0.64 mmol, 64\%) from 3-bromothiophene. $\mathrm{mp} 168-169{ }^{\circ} \mathrm{C}$ (EE/n-hexane); ${ }^{1} \mathrm{H}$ NMR (400 MHz, $\left.\mathrm{CDCl}_{3}\right) \delta 7.37$ (t, $J=7.3$
Hz, 1H), 7.48 (t, $J=7.7 \mathrm{~Hz}, 2 \mathrm{H}), 7.49$ (dd, $J=3.3$ and $5.4 \mathrm{~Hz}$, $1 \mathrm{H}), 7.53(\mathrm{dd}, J=1.5$ and $5.3 \mathrm{~Hz}, 1 \mathrm{H}), 7.61(\mathrm{dd}, J=1.4$ and 3.2 $\mathrm{Hz}, 1 \mathrm{H}), 7.90$ (d, $J=7.1 \mathrm{~Hz}, 2 \mathrm{H}), 8.10(\mathrm{~s}, 1 \mathrm{H}) ;{ }^{13} \mathrm{C}$ NMR $(100$ $\left.\mathrm{MHz}, \mathrm{CDCl}_{3}\right) \delta 114.14,117.93,120.85,125.89,127.29$, $128.45,128.92,130.15,148.01,154.99$; Anal. calcd for $\mathrm{C}_{12} \mathrm{H}_{9} \mathrm{~N}_{3} \mathrm{~S}: \mathrm{C}, 63.41 ; \mathrm{H}, 3.99 ; \mathrm{N}, 18.49 ; \mathrm{S}, 14.11$; found: $\mathrm{C}$, 63.51; H, 4.15; N, 18.46; S, 14.35; CIMS $m / z$ : (M + H) 228, (M $\left.-\mathrm{N}_{2}\right) 199,\left(\mathrm{M}-\mathrm{C}_{4} \mathrm{H}_{3} \mathrm{~N}_{2} \mathrm{~S}\right) 116$.

4-Phenyl-1-(thien-2-yl)-1H-1,2,3-triazole (9): 2-Iodothiophene $(\mathbf{3}, 0.11 \mathrm{~mL}, 1 \mathrm{mmol})$ or 2-bromothiophene $(3,0.10 \mathrm{~mL}$, $1 \mathrm{mmol})$, phenylacetylene $(0.11 \mathrm{~mL}, 1 \mathrm{mmol})$, sodium azide (130 mg, $2 \mathrm{mmol}$ ), copper(I) iodide (19 mg, $0.1 \mathrm{mmol}$ ), sodium ascorbate $(20 \mathrm{mg}, 0.1 \mathrm{mmol})$, DMEDA $(20 \mu \mathrm{L}, 0.2 \mathrm{mmol})$. According to method A the colorless product was obtained in $111 \mathrm{mg}(0.49 \mathrm{mmol}, 49 \%)$ from 2-iodothiophene and $120 \mathrm{mg}$ (0.53 mmol, 53\%) from 2-bromothiophene. $\mathrm{mp} 140-141{ }^{\circ} \mathrm{C}$ (from EE/n-hexane); ${ }^{1} \mathrm{H}$ NMR (400 MHz, $\left.\mathrm{CDCl}_{3}\right) \delta 7.07$ (dd, $J$ $=1.4$ and $5.5 \mathrm{~Hz}, 1 \mathrm{H}), 7.30(\mathrm{dd}, J=1.4$ and $3.8 \mathrm{~Hz}, 1 \mathrm{H}), 7.39$ (t, $J=7.4 \mathrm{~Hz}, 1 \mathrm{H}), 7.47$ (t, $J=7.5 \mathrm{~Hz}, 2 \mathrm{H}), 7.89$ (d, $J=7.1 \mathrm{~Hz}$, $2 \mathrm{H}), 8.10(\mathrm{~s}, 1 \mathrm{H}) ;{ }^{13} \mathrm{C} \mathrm{NMR}\left(100 \mathrm{MHz}, \mathrm{CDCl}_{3}\right) \delta 118.18$, $118.85,122.83,125.93,126.28,128.57,128.93,129.89,138.43$, 148.30; CIMS m/z: $(\mathrm{M}+\mathrm{H}) 228,\left(\mathrm{M}-\mathrm{N}_{2}\right)$ 199; Anal. calcd for $\mathrm{C}_{12} \mathrm{H}_{9} \mathrm{~N}_{3} \mathrm{~S}: \mathrm{C}, 63.41 ; \mathrm{H}, 3.99 ; \mathrm{N}, 18.49 ; \mathrm{S}, 14.11$; found: $\mathrm{C}$, 63.48; H, 4.03; N, 18.58; S, 13.92 .

4-(Thien-2-yl)-1-(thien-3-yl)-1H-1,2,3-triazole (10): 3-Iodothiophene $(\mathbf{1}, 0.13 \mathrm{~mL}, 1 \mathrm{mmol})$ or 3-bromothiophene $(0.10 \mathrm{~mL}$, $1 \mathrm{mmol})$, 2-ethynylthiophene $(4,0.11 \mathrm{mg}, 1 \mathrm{mmol})$, sodium azide (130 mg, $2 \mathrm{mmol}$ ), copper(I) iodide (19 mg, $0.1 \mathrm{mmol}$ ), sodium ascorbate $(20 \mathrm{mg}, 0.1 \mathrm{mmol})$, DMEDA $(20 \mu \mathrm{L}$, $0.2 \mathrm{mmol})$. According to method A the off-white product was obtained in $0.231 \mathrm{~g}(0.99 \mathrm{mmol}, 99 \%)$ from 3-iodothiophene and $0.11 \mathrm{~g}(0.47 \mathrm{mmol}, 47 \%)$ from 3-bromothiophene. $\mathrm{mp}$ 157-158 ${ }^{\circ} \mathrm{C}$ (from EE/n-hexane); ${ }^{1} \mathrm{H}$ NMR (400 MHz, $\mathrm{CDCl}_{3}$ ) $\delta 7.14(\mathrm{dd}, J=3.6$ and $5.1 \mathrm{~Hz}, 1 \mathrm{H}), 7.37(\mathrm{dd}, J=1.1$ and 5.1 $\mathrm{Hz}, 1 \mathrm{H}), 7.49$ (dd, $J=1.1$ and $3.5 \mathrm{~Hz}, 1 \mathrm{H}), 7.51(\mathrm{dd}, J=2.5$ and $5.6 \mathrm{~Hz}, 1 \mathrm{H}), 7.53(\mathrm{dd}, J=1.6$ and $5.3 \mathrm{~Hz}, 1 \mathrm{H}), 7.62(\mathrm{dd}, J=1.6$ and $3.1 \mathrm{~Hz}, 1 \mathrm{H}), 8.04(\mathrm{~s}, 1 \mathrm{H}) ;{ }^{13} \mathrm{C} \mathrm{NMR}\left(100 \mathrm{MHz}, \mathrm{CDCl}_{3}\right) \delta$ $100.00,114.31,117.41,120.83,124.61,125.42,127.35$, 127.71; CIMS $m / z$ : $(\mathrm{M}+\mathrm{H}) 234,\left(\mathrm{M}-\mathrm{N}_{2}\right) 206$, $(\mathrm{M}-$ $\left.\mathrm{C}_{4} \mathrm{H}_{3} \mathrm{~N}_{2} \mathrm{~S}\right)$ 122; HRMS-ESI $(\mathrm{m} / \mathrm{z})$ : $(\mathrm{M}+\mathrm{Na})$ calcd for $\mathrm{C}_{10} \mathrm{H}_{7} \mathrm{~N}_{3} \mathrm{NaS}_{2}$, 255.9974; found, 255.9981; $(\mathrm{M}+\mathrm{H})$ calcd for $\mathrm{C}_{10} \mathrm{H}_{8} \mathrm{~N}_{3} \mathrm{~S}_{2}$, 234.0154; found, 234.0157.

1,4-Di(thien-3-yl)-1H-1,2,3-triazole (11): 3-Iodothiophene (1, $0.11 \mathrm{~mL}, 1 \mathrm{mmol}), 3$-ethynylthiophene $(0.11 \mathrm{mg}, 1 \mathrm{mmol})$, sodium azide (130 mg, $2 \mathrm{mmol}$ ), copper(I) iodide (19 mg, $0.1 \mathrm{mmol})$, sodium ascorbate $(20 \mathrm{mg}, 0.1 \mathrm{mmol})$, DMEDA $(20 \mu \mathrm{L}, 0.2 \mathrm{mmol})$. The product was obtained, according to method A, in $0.23 \mathrm{~g} \mathrm{(0.99} \mathrm{mmol,} \mathrm{99 \% )} \mathrm{from} \mathrm{3-iodothiophene.}$ 
mp 206-207 ${ }^{\circ} \mathrm{C}$ (from EE); ${ }^{1} \mathrm{H}$ NMR (400 MHz, $\left.\mathrm{CDCl}_{3}\right) \delta 7.42$ $(\mathrm{dd}, J=3.0$ and $5.0 \mathrm{~Hz}, 1 \mathrm{H}), 7.48(\mathrm{dd}, J=3.1$ and $5.3 \mathrm{~Hz}, 1 \mathrm{H})$, $7.51(\mathrm{~m}, 2 \mathrm{H}), 7.60(\mathrm{dd}, J=1.5$ and $3.1 \mathrm{~Hz}, 1 \mathrm{H}), 7.76(\mathrm{dd}, J=$ 1.2 and $3.0 \mathrm{~Hz}, 1 \mathrm{H}), 8.01(\mathrm{~s}, 1 \mathrm{H}) ;{ }^{13} \mathrm{C} \mathrm{NMR}\left(100 \mathrm{MHz}, \mathrm{CDCl}_{3}\right)$ $\delta$ 114.13, 117.73, 120.86, 121.63, 125.83, 126.51, 127.31; Anal. calcd for $\mathrm{C}_{10} \mathrm{H}_{7} \mathrm{~N}_{3} \mathrm{~S}_{2}: \mathrm{C}, 51.48 ; \mathrm{H}, 3.02 ; \mathrm{N}, 18.01 ; \mathrm{S}, 27.49$; found: C, 51.58; H, 3.11; N, 17.98; S, 27.73; CIMS $m / z:(\mathrm{M}+$ H) 234, $\left(\mathrm{M}-\mathrm{N}_{2}\right) 206,\left(\mathrm{M}-\mathrm{C}_{4} \mathrm{H}_{3} \mathrm{~N}_{2} \mathrm{~S}\right) 122$.

4-(2,2'-Bithien-5-yl)-1-(thien-2-yl)-1H-1,2,3-triazole (12): 2-Iodothiophene (3, $0.11 \mathrm{~mL}, 1 \mathrm{mmol})$, 5-ethynyl-2,2'-bithiophene (190 mg, $1 \mathrm{mmol})$, sodium azide (130 mg, $2 \mathrm{mmol})$, copper(I) iodide (19 mg, $0.1 \mathrm{mmol})$, sodium ascorbate $(20 \mathrm{mg}$, $0.1 \mathrm{mmol})$, DMEDA $(20 \mu \mathrm{L}, 0.2 \mathrm{mmol})$. The greenish-white product was obtained by method A in $195 \mathrm{mg}(0.62 \mathrm{mmol}$, $62 \%$ ). mp $159-160{ }^{\circ} \mathrm{C} \mathrm{dec}$ (from toluene); ${ }^{1} \mathrm{H}$ NMR (400 MHz, $\left.\mathrm{CDCl}_{3}\right) \delta 7.04(\mathrm{dd}, J=3.8$ and $5.2 \mathrm{~Hz}, 1 \mathrm{H}), 7.06(\mathrm{dd}, J=3.7$ and $5.6 \mathrm{~Hz}, 1 \mathrm{H}), 7.17(\mathrm{~d}, J=3.8 \mathrm{~Hz}, 1 \mathrm{H}), 7.23(\mathrm{dd}, J=1.3$ and $3.7 \mathrm{~Hz}, 1 \mathrm{H}), 7.24(\mathrm{dd}, J=1.1$ and $2.1 \mathrm{~Hz}, 1 \mathrm{H}), 7.26(\mathrm{~m}, 1 \mathrm{H})$, $7.29(\mathrm{dd}, J=1.4$ and $3.8 \mathrm{~Hz}, 1 \mathrm{H}), 7.37$ (d, $J=3.8 \mathrm{~Hz}, 1 \mathrm{H}), 8.00$ $(\mathrm{s}, 1 \mathrm{H}) ;{ }^{13} \mathrm{C} \mathrm{NMR}\left(100 \mathrm{MHz}, \mathrm{CDCl}_{3}\right) \delta 18.16,118.39,123.04$, 124.08, 124.23, 124.78, 125.38, 126.33, 127.95, 130.67, 136.99, 137.62, 143.11; Anal. calcd for $\mathrm{C}_{14} \mathrm{H}_{9} \mathrm{~N}_{3} \mathrm{~S}_{3}$ : C, 53.31; H, 2.88; N, 13.32; S, 30.49; found: C, 53.27; H, 3.00; N, 13.24; S, 30.32; CIMS $m / z:(\mathrm{M}+\mathrm{H}) 316,\left(\mathrm{M}-\mathrm{N}_{2}\right) 288$.

1-(2,2'-Bithien-5-yl)-4-(thien-2-yl)-1H-1,2,3-triazole (13): 5-Iodo-2,2'-bithiophene (317 mg, $1 \mathrm{mmol})$, 2-ethynylthiophene (0.11 mg, $1 \mathrm{mmol})$, sodium azide (130 mg, $2 \mathrm{mmol})$, copper(I) iodide (19 mg, $0.1 \mathrm{mmol})$, sodium ascorbate $(20 \mathrm{mg}, 0.1 \mathrm{mmol})$, DMEDA $(20 \mu \mathrm{L}, 0.2 \mathrm{mmol})$. The pure greenish-white product was obtained by method A in $211 \mathrm{mg}(0.67 \mathrm{mmol}, 67 \%)$. mp 173-174 ${ }^{\circ} \mathrm{C}$ (from toluene); ${ }^{1} \mathrm{H} \mathrm{NMR}\left(400 \mathrm{MHz}, \mathrm{CDCl}_{3}\right) \delta 7.06$ (dd, $J=3.6$ and $5.1 \mathrm{~Hz}, 1 \mathrm{H}), 7.09(\mathrm{~d}, J=4.0 \mathrm{~Hz}, 1 \mathrm{H}), 7.12(\mathrm{dd}$, $J=3.6$ and $5.1 \mathrm{~Hz}, 1 \mathrm{H}), 7.18(\mathrm{~d}, J=4.0 \mathrm{~Hz}, 1 \mathrm{H}), 7.23(\mathrm{dd}, J=$ 1.1 and $3.6 \mathrm{~Hz}, 1 \mathrm{H}), 7.29(\mathrm{dd}, J=1.1$ and $5.1 \mathrm{~Hz}, 1 \mathrm{H}), 7.36(\mathrm{dd}$, $J=1.1$ and $5.1 \mathrm{~Hz}, 1 \mathrm{H}), 7.48(\mathrm{dd}, J=1.1$ and $3.6 \mathrm{~Hz}, 1 \mathrm{H}), 8.02$ $(\mathrm{s}, 1 \mathrm{H}) ;{ }^{13} \mathrm{C} \mathrm{NMR}\left(100 \mathrm{MHz}, \mathrm{CDCl}_{3}\right) \delta 117.79,118.45,122.29$, 124.64, 124.87, 125.50, 125.67, 127.76, 128.05, 131.95, 135.89; CIMS $m / z$ : $\left(\mathrm{M}^{+}\right) 316,\left(\mathrm{M}-\mathrm{N}_{2}\right)$ 288; HRMS-ESI $(\mathrm{m} / \mathrm{z})$ : $(\mathrm{M}+\mathrm{Na})$ calcd for $\mathrm{C}_{14} \mathrm{H}_{9} \mathrm{~N}_{3} \mathrm{NaS}_{3}, 337.9851$; found, 337.9847; $(\mathrm{M}+\mathrm{H})$ calcd for $\mathrm{C}_{14} \mathrm{H}_{10} \mathrm{~N}_{3} \mathrm{~S}_{3}, 316.0031$; found, 316.0026 .

1,4-Di(2,2'-bithien-5-yl)-1H-1,2,3-triazole (14): 5-Iodo-2,2'bithiophene (0.92 g, $1 \mathrm{mmol})$, 5-ethynyl-2,2'-bithiophene (0.19 mg, $1 \mathrm{mmol}$ ), sodium azide (130 mg, $2 \mathrm{mmol}$ ), copper(I) iodide (19 mg, $0.1 \mathrm{mmol})$, sodium ascorbate $(20 \mathrm{mg}, 0.1 \mathrm{mmol})$, DMEDA $(20 \mu \mathrm{L}, 0.2 \mathrm{mmol})$. The pure orange product was obtained by method B in $131 \mathrm{mg}(0.33 \mathrm{mmol}, 33 \%)$. The extraction with ethyl acetate failed because of the low solubility of the product. It was therefore extracted with THF. mp
235-236 ${ }^{\circ} \mathrm{C} \mathrm{dec}$ (from DCM/petrol ether); ${ }^{1} \mathrm{H}$ NMR (400 MHz, DMSO- $\left.d_{6}\right) \delta 7.13(\mathrm{dd}, J=3.6$ and $5.0 \mathrm{~Hz}, 1 \mathrm{H}), 7.15(\mathrm{dd}, J=3.6$ and $5.1 \mathrm{~Hz}, 1 \mathrm{H}), 7.36(\mathrm{~d}, J=3.7 \mathrm{~Hz}, 1 \mathrm{H}), 7.37(\mathrm{~d}, J=3.2 \mathrm{~Hz}$, $1 \mathrm{H}), 7.40(\mathrm{dd}, J=0.9$ and $3.5 \mathrm{~Hz}, 1 \mathrm{H}), 7.44(\mathrm{dd}, J=1.0$ and 3.6 $\mathrm{Hz}, 1 \mathrm{H}), 7.48(\mathrm{~d}, J=3.8 \mathrm{~Hz}, 1 \mathrm{H}), 7.54(\mathrm{~d}, J=4.0 \mathrm{~Hz}, 1 \mathrm{H}), 7.56$ $(\mathrm{dd}, J=0.9$ and $5.1 \mathrm{~Hz}, 1 \mathrm{H}), 7.61(\mathrm{dd}, J=1.0$ and $5.1 \mathrm{~Hz}, 1 \mathrm{H})$, $9.25(\mathrm{~s}, 1 \mathrm{H}) ;{ }^{13} \mathrm{C} \mathrm{NMR}\left(100 \mathrm{MHz}, \mathrm{DMSO}-d_{6}\right) \delta 115.79$, 119.39, 119.96, 123.52, 124.97, 125.21, 125.60, 126.35, 126.97, $128.95,129.02,130.91,134.14,135.61,135.90,136.48,136.86$, 142.86; CIMS m/z: $(\mathrm{M}+\mathrm{H}) 399,\left(\mathrm{M}-\mathrm{N}_{2}\right)$ 371; HRMS-ESI $(m / z):(\mathrm{M}+\mathrm{Na})$ calcd for $\mathrm{C}_{18} \mathrm{H}_{11} \mathrm{~N}_{3} \mathrm{NaS}_{4}, 419.9728$; found, 419.9716; $(\mathrm{M}+\mathrm{H})$ calcd for $\mathrm{C}_{18} \mathrm{H}_{12} \mathrm{~N}_{3} \mathrm{~S}_{4}$, 397.9909; found, 397.9907.

1-(5-Methylthien-2-yl)-4-(thien-2-yl)-1H-1,2,3-triazole (15): 2-Methyl-5-iodothiophene (224 mg, $1 \mathrm{mmol}), 2$-ethynylthiophene $(0.11 \mathrm{mg}, 1 \mathrm{mmol})$, sodium azide $(130 \mathrm{mg}, 2 \mathrm{mmol})$, copper(I) iodide (19 mg, $0.1 \mathrm{mmol}$ ), sodium ascorbate $(20 \mathrm{mg}$, $0.1 \mathrm{mmol})$, DMEDA ( $20 \mu \mathrm{L}, 0.2 \mathrm{mmol})$. According to method A the pure white product was obtained in $168 \mathrm{mg}(0.68 \mathrm{mmol}$, $68 \%$ ). mp $112{ }^{\circ} \mathrm{C} \mathrm{dec} \mathrm{(from} \mathrm{methanol);}{ }^{1} \mathrm{H} \mathrm{NMR}(400 \mathrm{MHz}$, $\left.\mathrm{CDCl}_{3}\right) \delta 2.52(\mathrm{~d}, J=1.0 \mathrm{~Hz}, 3 \mathrm{H}), 6.70(\mathrm{dd}, J=1.1$ and $3.7 \mathrm{~Hz}$, $1 \mathrm{H}), 7.06(\mathrm{dd}, J=3.7 \mathrm{~Hz}, 1 \mathrm{H}), 7.11(\mathrm{dd}, J=3.6$ and $5.1 \mathrm{~Hz}$, $1 \mathrm{H}), 7.34(\mathrm{dd}, J=1.1$ and $5.1 \mathrm{~Hz}, 1 \mathrm{H}), 7.45(\mathrm{dd}, J=1.1$ and 3.6 $\mathrm{Hz}, 1 \mathrm{H}), 7.95$ (s, $1 \mathrm{H}) ;{ }^{13} \mathrm{C} \mathrm{NMR}\left(100 \mathrm{MHz}, \mathrm{CDCl}_{3}\right) \delta 15.41$, 18.08, 118.41, 124.05, 124.68, 125.48, 127.70, 132.19, 144.63, 160.35, 160.56; Anal. calcd for $\mathrm{C}_{11} \mathrm{H}_{9} \mathrm{~N}_{3} \mathrm{~S}_{2}$ : C, 53.42; $\mathrm{H}, 3.67$; $\mathrm{N}, 16.99$; found: C, 53.17; H, 3.81; N, 16.76; CIMS m/z: (M + H) 248, $\left(\mathrm{M}-\mathrm{N}_{2}\right)$ 220; HRMS-ESI $(\mathrm{m} / \mathrm{z})$ : $(\mathrm{M}+\mathrm{Na})$ calcd for $\mathrm{C}_{11} \mathrm{H}_{9} \mathrm{~N}_{3} \mathrm{NaS}_{2}, 270.0130$; found, 270.0139; $(\mathrm{M}+\mathrm{H})$ calcd for $\mathrm{C}_{11} \mathrm{H}_{10} \mathrm{~N}_{3} \mathrm{~S}_{2}, 248.0311$; found, 248.0323 .

1-(3-Methylthien-2-yl)-4-(thien-2-yl)-1H-1,2,3-triazole (16): 2-Iodo-3-methylthiophene (224 mg, $1 \mathrm{mmol})$, 2-ethynylthiophene $(0.11 \mathrm{mg}, 1 \mathrm{mmol})$, sodium azide $(130 \mathrm{mg}, 2 \mathrm{mmol})$, copper(I) iodide (19 mg, $0.1 \mathrm{mmol})$, sodium ascorbate (20 mg, $0.1 \mathrm{mmol})$, DMEDA $(20 \mu \mathrm{L}, 0.2 \mathrm{mmol})$. The product was obtained according to method $\mathrm{B}$ as an oil in $29.6 \mathrm{mg}$ (0.12 mmol, 12\%). ${ }^{1} \mathrm{H}$ NMR (400 MHz, $\left.\mathrm{CDCl}_{3}\right) \delta 2.26$ (s, 3H), $6.91(\mathrm{~d}, J=5.6 \mathrm{~Hz}, 1 \mathrm{H}), 7.12(\mathrm{dd}, J=3.6$ and $5.1 \mathrm{~Hz}, 2 \mathrm{H}), 7.24$ $(\mathrm{d}, J=5.5 \mathrm{~Hz}, 1 \mathrm{H}), 7.34(\mathrm{dd}, J=1.1$ and $5.1 \mathrm{~Hz}, 1 \mathrm{H}), 7.46(\mathrm{dd}$, $J=1.0$ and $3.6 \mathrm{~Hz}, 1 \mathrm{H}), 7.90(\mathrm{~s}, 1 \mathrm{H}) ;{ }^{13} \mathrm{C} \mathrm{NMR}(100 \mathrm{MHz}$, $\left.\mathrm{CDCl}_{3}\right) \delta 13.47,121.12,123.27,124.67,125.50,127.74$, 129.20, 132.26, 132.91, 142.89; CIMS $m / z$ : $(\mathrm{M}+\mathrm{H}) 248$, (M$\left.\mathrm{N}_{2}\right)$ 219; HRMS-ESI $(m / z):(\mathrm{M}+\mathrm{Na})$ calcd for $\mathrm{C}_{11} \mathrm{H}_{9} \mathrm{~N}_{3} \mathrm{NaS}_{2}$, 270.0130; found, 270.0124 .

Ethyl 5-(4-(thien-2-yl)-1H-1,2,3-triazol-1-yl)thiophene-2carboxylate (17): Ethyl 2-iodo-5-thiophenecarboxylate (345 mg, $1 \mathrm{mmol}), 2$-ethynylthiophene $(0.11 \mathrm{mg}, 1 \mathrm{mmol})$, sodium azide (130 mg, $2 \mathrm{mmol}$ ), copper(I) iodide (19 mg, 
$0.1 \mathrm{mmol})$, sodium ascorbate $(20 \mathrm{mg}, 0.1 \mathrm{mmol})$, DMEDA ( $20 \mu \mathrm{L}, 0.2 \mathrm{mmol}$ ). According to procedure $\mathrm{B}$ the product was obtained as a colorless solid in $186 \mathrm{mg}(0.61 \mathrm{mmol}, 61 \%) . \mathrm{mp}$ $135{ }^{\circ} \mathrm{C} \mathrm{dec}$ (from DCM/petrol ether); ${ }^{1} \mathrm{H}$ NMR (400 MHz, $\left.\mathrm{CDCl}_{3}\right) \delta 1.40(\mathrm{t}, J=7.1 \mathrm{~Hz}, 3 \mathrm{H}), 4.39(\mathrm{q}, J=7.1 \mathrm{~Hz}, 2 \mathrm{H}), 7.13$ $(\mathrm{dd}, J=3.6$ and $5.1 \mathrm{~Hz}, 1 \mathrm{H}), 7.28(\mathrm{~d}, J=4.1 \mathrm{~Hz}, 1 \mathrm{H}), 7.37(\mathrm{dd}$ $J=1.1$ and $5.1 \mathrm{~Hz}, 1 \mathrm{H}), 7.49(\mathrm{dd}, J=1.1$ and $3.6 \mathrm{~Hz}, 1 \mathrm{H}), 7.74$ $(\mathrm{d}, J=4.1 \mathrm{~Hz}, 1 \mathrm{H}), 8.05$ (s, 1H); ${ }^{13} \mathrm{C} \mathrm{NMR}\left(100 \mathrm{MHz}, \mathrm{CDCl}_{3}\right)$ $\delta 14.29,61.75,117.45,117.50,125.14,125.94,127.82,130.61$, 131.55, 132.44, 143.87, 161.49; Anal calcd for $\mathrm{C}_{13} \mathrm{H}_{11} \mathrm{~N}_{3} \mathrm{O}_{2} \mathrm{~S}_{2}$ : C, 51.13; H, 3.63; N, 13.76; S, 21.00; found: C, 51.12; H, 3.71; $\mathrm{N}, 13.72$; S, 21.07; CIMS $m / z$ : $(\mathrm{M}+\mathrm{H}) 306,\left(\mathrm{M}-\mathrm{N}_{2}\right) 278$, (M $\left.-\mathrm{C}_{2} \mathrm{H}_{5} \mathrm{~N}_{2}\right) 250$.

Ethyl 2-(4-(thien-2-yl)-1H-1,2,3-triazol-1-yl)thiophene-3carboxylate (18): Ethyl 2-iodo-3-thiophenecarboxylate (345 mg, $1 \mathrm{mmol})$, 2-ethynylthiophene $(0.11 \mathrm{mg}, 1 \mathrm{mmol})$, sodium azide (130 mg, $2 \mathrm{mmol})$, copper(I) iodide (19 mg, $0.1 \mathrm{mmol})$, sodium ascorbate $(20 \mathrm{mg}, 0.1 \mathrm{mmol})$, DMEDA $(20 \mu \mathrm{L}, 0.2 \mathrm{mmol})$. According to procedure B no product could be isolated.

1-[5,5'-Bis(trimethylsilyl)-[2,2':3',2''-terthien]-5'-yl]-4(thien-2-yl)-1H-1,2,3-triazole (19): 5'-Iodo-5,5"bis(trimethylsilyl)-[2,2':3',2"-terthiophene] (259 mg, $0.5 \mathrm{mmol})$, 2-ethynylthiophene ( $54 \mathrm{mg}, 0.5 \mathrm{mmol})$, sodium azide $(65 \mathrm{mg}$, $1 \mathrm{mmol})$, copper(I) iodide $(10 \mathrm{mg}, 50 \mu \mathrm{mol})$, sodium ascorbate (10 mg, $50 \mu \mathrm{mol})$, DMEDA $(10 \mu \mathrm{L}, 0.1 \mathrm{mmol})$. By method B the product was obtained in $111 \mathrm{mg}(0.205 \mathrm{mmol}, 41 \%)$ as yellowish needles. mp $119-120{ }^{\circ} \mathrm{C}$ (from petrol ether); ${ }^{1} \mathrm{H}$ NMR $\left(400 \mathrm{MHz}, \mathrm{CDCl}_{3}\right) \delta 0.32(2 \times \mathrm{s}, 18 \mathrm{H}), 7.11(\mathrm{dd}, J=$ 3.7 and $5.2 \mathrm{~Hz}, 1 \mathrm{H}), 7.13-7.16(\mathrm{~m}, 3 \mathrm{H}), 7.22(\mathrm{~d}, J=3.4 \mathrm{~Hz}$, $1 \mathrm{H}), 7.34(\mathrm{~s}, 1 \mathrm{H}), 7.35(\mathrm{dd}, J=1.0$ and $5.1 \mathrm{~Hz}, 1 \mathrm{H}), 7.48(\mathrm{dd}, J$ $=1.0$ and $3.5 \mathrm{~Hz}, 1 \mathrm{H}), 8.03(\mathrm{~s}, 1 \mathrm{H}) ;{ }^{13} \mathrm{C} \mathrm{NMR}(100 \mathrm{MHz}$, $\left.\mathrm{CDCl}_{3}\right) \delta-0.15,-0.1,117.52,120.04,124.89,125.68,127.75$, 128.21, 128.67, 129.62, 130.77, 131.91, 134.21, 135.88, 138.46, $141.37,141.55,143.18,143.45,143.53,145.41$; HRMS-ESI $(m / z):(\mathrm{M}+\mathrm{Na})$ calcd for $\mathrm{C}_{24} \mathrm{H}_{27} \mathrm{~N}_{3} \mathrm{NaS}_{4} \mathrm{Si}_{2}, 564.0519$; found, 564.0513 .

4-[5,5'-Bis(trimethylsilyl)-[2,2':3',2' '-terthien]-5'-yl]-1(thien-2-yl)-1H-1,2,3-triazole (20): 2-Iodothiophene $(0.03 \mathrm{~mL}$, $0.25 \mathrm{mmol}$ ), 2-[5,5"-bis(trimethylsilyl)-[2,2':3',2"-terthien]-5'yl] ethynyl-1-trimethylsilane (125 mg, $0.3 \mathrm{mmol})$, sodium azide (35 mg, $0.5 \mathrm{mmol}$ ), copper(I) iodide ( $5 \mathrm{mg}, 25 \mu \mathrm{mol}$ ), sodium ascorbate $(5 \mathrm{mg}, 25 \mu \mathrm{mol})$, DMEDA $(5 \mu \mathrm{L}, 50 \mu \mathrm{mol})$. By method A the product was obtained as yellow solid in $124 \mathrm{mg}$ (0.23 mmol, 92\%). mp $129-130{ }^{\circ} \mathrm{C}$ (from petrol ether); ${ }^{1} \mathrm{H}$ NMR $\left(400 \mathrm{MHz}, \mathrm{CDCl}_{3}\right) \delta 0.32(2 \times \mathrm{s}, 18 \mathrm{H}), 7.07(\mathrm{dd}, J=$ 3.8 and $5.4 \mathrm{~Hz}, 1 \mathrm{H}), 7.12-7.15(\mathrm{~m}, 3 \mathrm{H}), 7.21(\mathrm{~d}, J=3.5 \mathrm{~Hz}$, $1 \mathrm{H}), 7.25(\mathrm{~m}, 1 \mathrm{H}), 7.29(\mathrm{dd}, J=1.3$ and $3.8 \mathrm{~Hz}, 1 \mathrm{H}), 7.52$ (s,
1H), $8.02(\mathrm{~s}, 1 \mathrm{H}) ;{ }^{13} \mathrm{C} \mathrm{NMR}\left(100 \mathrm{MHz}, \mathrm{CDCl}_{3}\right) \delta-0.09,-0.04$, $118.29,118.40,123.06,126.34,127.47,127.86,128.94,130.28$, 131.73, 132.29, 134.20, 138.13, 139.79, 140.87, 142.30, 142.50, 142.76; CIMS $m / z$ : $(\mathrm{M}+\mathrm{H})$ 542, $\left(\mathrm{M}-\mathrm{N}_{2}\right)$ 513, $(\mathrm{M}-$ $\left.\mathrm{Si}\left(\mathrm{CH}_{3}\right)_{3}\right) 470,\left(\mathrm{M}-\mathrm{N}_{2} \mathrm{Si}\left(\mathrm{CH}_{3}\right)_{3}\right) 441,\left(\mathrm{M}-2 \mathrm{Si}\left(\mathrm{CH}_{3}\right)_{3}\right) 398$; HRMS-ESI $(\mathrm{m} / \mathrm{z}):(\mathrm{M}+\mathrm{Na})$ calcd. for $\mathrm{C}_{24} \mathrm{H}_{27} \mathrm{~N}_{3} \mathrm{NaS}_{4} \mathrm{Si}_{2}$, 564.0519 ; found, 564.0514 .

\section{1,4-Phenylene-bis(4'-(thien-2''-yl)-1' H-1',2',3'-triazol-1'-yl)} (21): 1,4-Diiodobenzene (330 mg, $1 \mathrm{mmol})$ or 1,4-dibromobenzene (236 mg, $1 \mathrm{mmol})$, 2-ethynylthiophene ( $0.22 \mathrm{mg}, 2 \mathrm{mmol})$, sodium azide ( $260 \mathrm{mg}, 4 \mathrm{mmol})$, cupric sulfate pentahydrate (50 mg, $0.2 \mathrm{mmol}$ ), sodium ascorbate $(40 \mathrm{mg}, 0.2 \mathrm{mmol})$, DMEDA $(40 \mu \mathrm{L}, 0.4 \mathrm{mmol})$. The reaction was performed in DMSO-water (9:1). 1,4-Diiodobenzene yielded in $372 \mathrm{mg}$ $(0.99 \mathrm{mmol}, 99 \%)$ at $50{ }^{\circ} \mathrm{C}$, from 1,4-dibromobenzene the disubstituted product was obtained in $368.5 \mathrm{mg}(0.98 \mathrm{mmol}$, 98\%) at $95{ }^{\circ} \mathrm{C} . \mathrm{mp} 310^{\circ} \mathrm{C} \mathrm{dec} \mathrm{(from} \mathrm{toluene);}{ }^{1} \mathrm{H}$ NMR (400 MHz, THF- $\left.d_{8}\right) \delta 7.09(\mathrm{dd}, J=3.6$ and $5.1 \mathrm{~Hz}, 2 \mathrm{H}), 7.41(\mathrm{dd}, J$ $=1.1$ and $5.1 \mathrm{~Hz}, 2 \mathrm{H}), 7.50(\mathrm{dd}, J=1.1$ and $3.6 \mathrm{~Hz}, 2 \mathrm{H}), 8.15$ $(\mathrm{s}, 4 \mathrm{H}), 8.77(\mathrm{~s}, 2 \mathrm{H}) ;{ }^{13} \mathrm{C}$ NMR (100 MHz, DMSO-d 6$) \delta$ 100.00, 119.47, 121.89, 125.26, 126.59, 128.56, 132.63, 136.68, 143.41; CIMS $m / z$ : $(\mathrm{M}+\mathrm{H}) 377,\left(\mathrm{M}-\mathrm{N}_{2}\right) 349,\left(\mathrm{M}-\mathrm{N}_{4}\right) 320$; HRMS-ESI $(m / z):(\mathrm{M}+\mathrm{Na})$ calcd for $\mathrm{C}_{18} \mathrm{H}_{12} \mathrm{~N}_{6} \mathrm{NaS}_{2}$, 399.0457 ; found, 399.0452 .

\section{References}

1. Mishra, A.; Ma, C.-Q.; Bäuerle, P. Chem. Rev. 2009, 109, 1141-1276. doi:10.1021/cr8004229

2. Perepichka, I. F.; Perepichka, D. F., Eds. Handbook of Thiophene-Based Materials: Applications in Organic Electronics and Photonics; Wiley-VCH: Weinheim, Germany, 2009.

3. Müllen, K.; Wegner, G., Eds. Electronic Materials: The Oligomer Approach; Wiley-VCH: Weinheim, Germany, 1998.

4. Stille, J. K. Angew. Chem., Int. Ed. Engl. 1986, 25, 508-524. doi:10.1002/anie.198605081

5. Miyaura, N.; Suzuki, A. Chem. Rev. 1995, 95, 2457-2483. doi:10.1021/cr00039a007

6. Littke, A. F.; Fu, G. C. Angew. Chem., Int. Ed. 2002, 41, 4176-4211. doi:10.1002/1521-3773(20021115)41:22<4176::AID-ANIE4176>3.0.CO ;2-U

7. Doucet, H.; Hierso, J.-C. Angew. Chem., Int. Ed. 2007, 46, 834-871. doi:10.1002/anie.200602761

8. Negishi, E.; Anastasia, L. Chem. Rev. 2003, 103, 1979-2018. doi:10.1021/cr020377i

9. de Meijere, A.; Diederich, F., Eds. Metal-Catalyzed Cross-Coupling Reactions; Wiley-VCH: Weinheim, Germany, 2004.

10. Kolb, H. C.; Finn, M. G.; Sharpless, K. B. Angew. Chem., Int. Ed. 2001, 40, 2004-2021.

doi:10.1002/1521-3773(20010601)40:11<2004::AID-ANIE2004>3.0.CO ;2-5

Angew. Chem. 2001, 113, 2056-2075.

doi:10.1002/1521-3757(20010601)113:11<2056::AID-ANGE2056>3.3. $\mathrm{CO} ; 2-\mathrm{N}$ 
11. Wu, P.; Feldman, A. K.; Nugent, A. K.; Hawker, C. J.; Scheel, A.; Voit, B.; Pyun, J.; Fréchet, J. M. J.; Sharpless, K. B.; Fokin, V. V. Angew. Chem., Int. Ed. 2004, 43, 3928-3932. doi:10.1002/anie.200454078

12. Bock, V. D.; Hiemstra, H.; van Maarseveen, J. H. Eur. J. Org. Chem. 2006, 51-68. doi:10.1002/ejoc.200500483

13. Lutz, J.-F. Angew. Chem., Int. Ed. 2007, 46, 1018-1025. doi:10.1002/anie.200604050 Angew. Chem. 2007, 119, 1036-1043. doi:10.1002/ange.200604050

14. Wu, P.; Fokin, V. V. Aldrichimica Acta 2007, 40, 7-17.

15. Parent, M.; Mongin, O.; Kamada, K.; Katan, C.; Blanchard-Desce, M. Chem. Commun. 2005, 2029-2031. doi:10.1039/b419491h

16. Kappe, C. O.; Van der Eycken, E. Chem. Soc. Rev. 2010, 39, 1280-1290. doi:10.1039/b901973c

17. de Miguel, G.; Wielopolski, M.; Schuster, D. I.; Fazio, M. A.; Lee, O. P.; Haley, C. K.; Ortiz, A. L.; Echegoyen, L.; Clark, T.; Guldi, D. M. J. Am. Chem. Soc. 2011, 133, 13036-13054. doi:10.1021/ja202485s

18. Hänni, K. D.; Leigh, D. A. Chem. Soc. Rev. 2010, 39, 1240-1251. doi:10.1039/b901974j

19. Malkoch, M.; Schleicher, K.; Drockenmuller, E.; Hawker, C. J.; Russell, T. P.; Wu, P.; Fokin, V. V. Macromolecules 2005, 38, 3663-3678. doi:10.1021/ma047657f

20. Ornelas, C.; Aranzaes, J. R.; Cloutet, E.; Alves, S.; Astruc, D. Angew. Chem., Int. Ed. 2007, 46, 872-877. doi:10.1002/anie.200602858 Angew. Chem. 2007, 119, 890-895. doi:10.1002/ange.200602858

21. van Steenis, D. J. V. C.; David, O. R. P.; van Strijdonck, G. P. F.; van Maarseveen, J. H.; Reek, J. N. H. Chem. Commun. 2005, 4333-4335. doi:10.1039/b507776a

22. Nagarjuna, G.; Yurt, S.; Jadhav, K. G.; Venkataraman, D. Macromolecules 2010, 43, 8045-8050. doi:10.1021/ma101657e

23. Golas, P. L.; Matyjaszewski, K. Chem. Soc. Rev. 2010, 39, 1338-1354. doi:10.1039/b901978m

24. Burley, G. A.; Gierlich, J.; Mofid, M. R.; Nir, H.; Tal, S.; Eichen, Y.; Carell, T. J. Am. Chem. Soc. 2006, 128, 1398-1399. doi:10.1021/ja055517v

25. El-Sagheer, A. H.; Brown, T. Chem. Soc. Rev. 2010, 39, 1388-1405. doi:10.1039/b901971p

26. Zhou, Z.; Fahrni, C. J. J. Am. Chem. Soc. 2004, 126, 8862-8863. doi:10.1021/ja049684r

27. Lau, Y. H.; Rutledge, P. J.; Watkinson, M.; Todd, M. H. Chem. Soc. Rev. 2011, 40, 2848-2866. doi:10.1039/c0cs00143k

28. Struthers, H.; Mindt, T. L.; Schibli, R. Dalton Trans. 2010, 39, 675-696. doi:10.1039/b912608b

29. Happ, B.; Escudero, D.; Hager, M. D.; Friebe, C.; Winter, A.; Görls, H.; Altuntas, E.; González, L.; Schubert, U. S. J. Org. Chem. 2010, 75, 4025-4038. doi:10.1021/jo100286r

30. Stengel, I.; Mishra, A.; Pootrakulchote, N.; Moon, S.-J.; Zakeeruddin, S. M.; Grätzel, M.; Bäuerle, P. J. Mater. Chem. 2011, 21, 3726-3734. doi:10.1039/c0jm03750h

31. Wild, A.; Friebe, C.; Winter, A.; Hager, M. D.; Grummt, U.-W.; Schubert, U. S. Eur. J. Org. Chem. 2010, 1859-1868. doi:10.1002/ejoc.200901112

32. Andersen, J.; Madsen, U.; Björkling, F.; Liang, X. Synlett 2005, 2209-2213. doi:10.1055/s-2005-872248

33. Valenti, F.; Zanirato, P. J. Chem. Soc., Perkin Trans. 2 1999, 623-628. doi:10.1039/a807350c

34. Feldmann, A. K.; Colasson, B.; Fokin, V. V. Org. Lett. 2004, 6, 3897-3899. doi:10.1021/ol048859z

35. Kacprzak, K. Synlett 2005, 6, 943-946. doi:10.1055/s-2005-864809
36. Chittaboina, S.; Xie, F.; Wang, Q. Tetrahedron Lett. 2005, 46, 2331-2336. doi:10.1016/j.tetlet.2005.01.175

37. Spagnolo, P.; Zanirato, P. J. Org. Chem. 1978, 43, 3539-3541. doi:10.1021/jo00412a027

38. Cymermann-Craig, J.; Harrisson, R. J. Aust. J. Chem. 1955, 8, 378-384. doi:10.1071/CH9550378

39. Jenekhe, S. A.; Lu, L.; Alam, M. M. Macromolecules 2001, 34, 7315-7324. doi:10.1021/ma0100448

40. Garcia, P.; Pernaut, J. M.; Hapiot, P.; Wintgens, V.; Valat, P.; Garnier, F.; Delabouglise, D. J. Phys. Chem. 1993, 97, 513-516. doi:10.1021/j100104a040

41. Luker, T. J.; Beaton, H. G.; Whiting, M.; Mete, A.; Cheshire, D. R. Tetrahedron Lett. 2000, 41, 7731-7735. doi:10.1016/S0040-4039(00)01307-1

42. Adams, R. N. Electrochemistry at Solid Electrodes; Dekker: New York, 1969; pp 143-169.

43. Eaton, D. F. Pure Appl. Chem. 1988, 60, 1107-1114. doi:10.1351/pac198860071107

44. Mishra, A.; Ma, C.-Q.; Janssen, R. A. J.; Bäuerle, P. Chem.-Eur. J. 2009, 15, 13521-13534. doi:10.1002/chem.200901242

45. Spinelli, D.; Zanirato, P. J. Chem. Soc., Perkin Trans. 2 1993, 1129-1133. doi:10.1039/p29930001129

\section{License and Terms}

This is an Open Access article under the terms of the Creative Commons Attribution License (http://creativecommons.org/licenses/by/2.0), which permits unrestricted use, distribution, and reproduction in any medium, provided the original work is properly cited.

The license is subject to the Beilstein Journal of Organic Chemistry terms and conditions:

(http://www.beilstein-journals.org/bjoc)

The definitive version of this article is the electronic one which can be found at: doi:10.3762/bjoc. 8.76 